6 British Medical Association. Young people and alcohol. London: BMA, 1986. 7 Swadi H. Substance use in a population of London adolescents. London: University of London, 1989. (M Phil thesis.)

8 Friedman J, Humphrey J. Antecedents of collegiate drinking. Fournal of Youth and Adolescence 1985; 14: 11-21.

9 Barnes G, Welte J. Patterns and predictors of alcohol use among 1-12th grade students in New York State. F Stud Alcohol 1986; 47: 53-62.

10 Jellinek E. The disease concept of alcoholism. New Jersey: Hillhouse Press, 1960.

11 Pendleton L, Smith C, Roberts J. Drinking on television: a content analysis of endleton L, Smith C, Roberts J. Drinking on television:
recent alcohol portrayal. Br $\mathcal{J}$ Addict 1991; 86: 769-74.

12 Wyllie A, Casswell S, Stewart J. The response of New Zealand boys to corporate and sponsorship alcohol advertising on television. Br $\mathcal{F}$ Addict $1989 ; 84: 639-46$.

13 Aitkin P, Eadie D, Leathar D, McNeil R, Scott A. Television advertisements for alcoholic drinks do reinforce under-age drinking. $\mathrm{Br} \mathcal{F}$ Addict 1988; 83 : $1399-419$.

14 Schuckit $M$. Subjective responses to alcohol in sons of alcoholics and control subjects. Arch Gen Psychiatry 1984; 41: 879-84.

15 Begleiter H, Porjesz B. Neuroelectric processes in individuals at risk for alcoholism. Alcohol Alcohol 1990; 25: 251-6.

16 Rowe D, Rodgers J. Adolescent smoking and drinking: are they 'epidemics'? f Stud Alcohol 1991; 52: 110-7.

17 Pedersen W. Drinking games adolescents play. Br $\mathcal{F}$ Addict 1990; 85: 1483-90. 18 Romelsjo A. Decline in alcohol-related problems in Sweden greatest among young people. Brf Addict 1987; 82: 1111-24.

19 Labouvie E. Alcohol and marijuana use in relation to adolescent stress. Int $\mathcal{F}$ Addict 1986; 21: 333-45.

20 Deykin E, Levy J, Wells V. Adolescent depression, alcohol and drug abuse. Am $\mathcal{F}$ Public Health 1987; 77: 178-82.

21 Singer $M$, Petchers $M$. The relationship between sexual abuse and substance abuse among psychiatrically hospitalised adolescents. Child Abuse Negl 1989, 13: $319-25$.
22 Goldbloom D, Naranjo C, Bremner K, Hicks L. Eating disorders and alcohol abuse in women. BrF Addict 1992; 87: 913-20.

23 Lavik N, Clausen S, Pedersen W. Eating behaviour, drug use, psychopathology and parental bonding in adolescents in Norway. Acta Psychiat Scand 1991; 84: 387-90.

24 Andersson T, Bergman L, Magnusson D. Patterns of adjustment problems and alcohol abuse in early adulthood: a prospective longitudinal study. Developmental Psychopathology 1989; 1: 119-31.

25 Ghodesian M, Power C. Alcohol consumption between the ages of 16 and 23 in Britain: a longitudinal study. Br f Addict 1987; 82: 175-80.

26 Andersson T, Magnusson D. Drinking habits and alcohol abuse among young men - a prospective longitudinal study. F Stud Alcohol 1988; 49: 245-52.

27 Thunstrom M. The alcohol intoxicated child and its prognosis. Acta Paediatr Scand 1988; 77: 3-9.

28 Friedman A, Glickman N. Program characteristics from successful treatment of adolescent drug abuse. F Nerv Ment Dis 1986; 174: 669-79.

29 Alford G, Koehler R, Leonard J. Alcoholics anonymous - narcotic anonymous model inpatient treatment of chemically dependent adolescents: a 2-year outcome study. F Stud Alcohol 1991; 52: 118-26.

30 Fishman H, Stanton D, Rosman B. Treating families of adolescent drug abusers. In: Stanton M, Todd T, eds. The family therapy of drug abuse and addiction. New York: Guilford, 1982: 335-57.

31 Bagnall G. Alcohol education for 13-year olds - does it work? Results from a controlled evaluation. Brf Addict 1990; 85: 89-96.

32 Goodwin D. Biological factors in alcohol use and abuse: implications for recognising and preventing alcohol problems in adolescence. Intermational Reviews of Psychiatry 1989; 1: 41-9.

33 Williams T, Lillis R. Long term changes in reported alcohol purchasing and consumption following an increase in New York states purchase age to 19. Br f Addict 1988; 83: 209-17.

34 Chou P, Pickering R. Early onset of drinking as a risk factor for lifetime alcoholrelated problems. Br f Addict 1992; 87: 1199-204.

\title{
Androgen insensitivity syndrome
}

Numerous clinical syndromes are now recognised to be associated with resistance to the action of hormones in target tissues. ' There is no clearer clinical example of this phenomenon than the development of an external female phenotype in a genetic male, in whom there is total resistance to the action of androgens, the so called androgen insensitivity syndrome. ${ }^{2}$ Approximately two thirds of cases of androgen insensitivity are familial with an $\mathrm{X}$ linked pattern of inheritance.

\section{Clinical phenotypes}

Two phenotypic forms of the androgen insensitivity syndrome are recognised. The complete form (CAIS), previously known as the testicular feminisation syndrome, ${ }^{3}$ is associated with normal female external genitalia. The condition may present in infancy or childhood with labial swellings or inguinal hernias that are found to contain testes. More typically, CAIS presents in late adolescence with primary amenorrhoea. There is absence of female internal genitalia on ultrasound scan or laparoscopy and testicular histology shows spermatogenesis to be incomplete or absent, although Leydig cells are abundant. Plasma testosterone concentrations are within the age appropriate male range or in some instances even higher as a result of the increased stimulation by luteinising hormone.

The partial form of the androgen insensitivity syndrome (PAIS) is associated with a wide range of genital abnormalities, and typically presents at birth with genital ambiguity. Severe hypospadias and associated abnormalities such as a micropenis, bifid scrotum, and bilateral cryptorchidism are common. Alternatively, the external genital phenotype may be predominantly female with partial labial fusion and clitoromegaly. Clinically milder forms of PAIS may also include isolated familial hypospadias and some cases of infertility in otherwise phenotypically normal males. ${ }^{2}$ The diagnosis of PAIS depends on demonstrating a normal testosterone response to human chorionic gonadotrophin
(HCG) stimulation. Measurement of steroid precursors in plasma and their metabolites in urine after HCG stimulation should exclude other testosterone biosynthetic defects. ${ }^{4}$ Pelvic ultrasound generally shows absence of female internal genitalia, although vaginal remnants may persist. As male pseudohermaphroditism due to a number of different causes may present with a clinical phenotype similar to PAIS, careful evaluation is clearly important to optimise management.

\section{Investigation}

The following approach is suggested for the investigation of patients with male pseudohermaphroditism. Examination of the internal genitalia by ultrasound scan or by laparoscopy is needed to look for evidence of müllerian structures such as a uterus. An opportunity should be taken at the time of any reconstructive surgery to examine, if possible, gonadal histology in case of dysplasia or true hermaphroditism. An HCG stimulation test (1500 units daily for three days) with normal testosterone production is a prerequisite if a diagnosis of PAIS is to be considered. Testosterone biosynthetic defects can be excluded by measurement of precursor steroids such as 17 hydroxyprogesterone, androstenedione, dehydroepiandrosterone and its sulphate. ${ }^{5}$ The autosomal recessive disorder, $5 \alpha$-reductase deficiency, can be excluded by measurement of testosterone and dihydrotestosterone in plasma together with $5 \alpha$ - and $5 \beta$-reduced androgen metabolites in urine after HCG stimulation. ${ }^{6}$ Further information about possible androgen insensitivity can be obtained from androgen binding studies and molecular analysis of the androgen receptor gene.

\section{Androgen binding studies}

The evidence that androgen insensitivity occurs because of some abnormality in the androgen receptor was first obtained 
from assays of androgen binding activity in genital skin fibroblasts. ${ }^{7}$ A range of androgen binding abnormalities have been defined, but a general classification describes binding as negative, deficient, or positive. The majority of patients with CAIS have negative or deficient binding, whereas PAIS is usually associated with positive binding. Qualitative defects in androgen binding are found in approximately $10 \%$ of patients with PAIS.

\section{Androgen receptor gene studies}

An added impetus was given to the understanding of androgen insensitivity syndrome when the gene for the androgen receptor was cloned. ${ }^{910}$ The gene is located on the long arm of the X chromosome, Xq11-12, ${ }^{11}$ and is comprised of eight exons encoding three clearly defined functional domains. ${ }^{2}$ The $\mathrm{C}$ terminal domain is encoded by five exons and is responsible for receptor binding to androgen; a central domain encoded by two exons is involved in the binding of receptor to chromosomal DNA; the $\mathrm{N}$ terminal domain is encoded by one large exon. This domain is the least well characterised and is involved in the receptor's role in gene regulation.

A number of mutations of the androgen receptor gene have now been reported in both CAIS and PAIS. ${ }^{212}$ The vast majority are point mutations involving a single nucleotide change, which may result in the substitution of one amino acid for another in the protein sequence or may substitute a stop codon for an amino acid codon so producing a truncated receptor protein. As expected, when androgen binding is altered, mutations are generally found in the $C$ terminal androgen binding domain. An androgen receptor gene mutation affecting the androgen binding domain has recently been identified in a pair of brothers with severe perineal hypospadias. This was the only manifestation of undervirilisation in these patients and suggests that isolated familial hypospadias represents a variant of PAIS. ${ }^{13}$ Mutations have also been identified in the two exons encoding the DNA binding domain of the androgen receptor. ${ }^{14}$ In a CAIS family containing two affected siblings, one of the two exons encoding the DNA binding domain was completely deleted in the affected individuals. ${ }^{15}$ Androgen binding is normal in such instances and the phenotype is the result of impaired binding of the androgen-receptor complex to chromosomal DNA.

The evidence to date indicates that a mutation of the androgen receptor gene is responsible for most if not all cases of CAIS. In contrast, many patients with PAIS demonstrate no defect in androgen binding and no androgen receptor gene mutation can be identified. ${ }^{12}$ In such cases, it must be assumed that partial androgen insensitivity is the result of defects in other genes which must have a role in sexual development. Mutational analysis of the androgen receptor gene has greatly enhanced our understanding of the molecular basis of androgen insensitivity and the normal mode of action of the androgen receptor. It has also improved the possibilities for genetic counselling for affected families and has allowed prenatal diagnosis to be offered.

\section{Management}

Management of CAIS is relatively straightforward as the sex of rearing is always female. However, appropriate counselling of parents in which clear and accurate information is given about longer term issues of hormone replacement and fertility must be carried out by an experienced endocrinologist. Reconstructive surgery to the external genitalia is not required but the gonads need to be removed because of the risk of malignancy. ${ }^{16}{ }^{17}$ The timing of this varies, but there is now a tendency to proceed with gonadectomy early, rather than to wait until after puberty.
Management of PAIS is more complicated. The critical problem is the current lack of a reliable indicator of whether an infant reared as male will virilise at puberty. Trying to establish a precise diagnosis is clearly important, but often takes a considerable time. The paediatric surgeon must be involved at an early stage when assessing the anatomy of the external genitalia. Occasionally, a trial of androgen treatment with, for example, a course of monthly injections of testosterone enanthate $(25 \mathrm{mg}$ ) for two to three months may be required, before finally deciding whether a severely undervirilised infant can be reared as a male. It is important to delay birth registration until a decision has been made. Although the term PAIS implies that virilisation will not occur in the long term, this may not be the case, even when there is a mutation of the androgen receptor gene. ${ }^{18}$ PAIS patients reared as females require appropriate genital surgery and gonadectomy performed early and oestrogen replacement at the time of puberty. In PAIS males, repairing a severe hypospadias and bringing the testes down into a normal scrotal sac is a task most surgeons choose to perform at about 3 years of age. Preoperative androgen treatment may produce phallic growth and facilitate surgical reconstruction.

The androgen insensitivity syndrome is currently one of the subjects of study undertaken through the auspices of the British Paediatric Surveillance Unit. The survey should provide details on precise diagnosis as well as some indication of the incidence and prevalence of the condition. It is only when such information becomes available that it is possible that recent knowledge of the molecular biology of androgen action may be used to predict the longer term outcome of androgen insensitive patients reared as males.

DENISE M WILLIAMS MARK N PATTERSON IEUAN A HUGHES

Department of Paediatrics,

University of Cambridge,

Addenbrooke's Hospital,

Hills Road, Cambridge CB2 $2 Q Q$

1 Albright F, Butler A, Bloomberg E. Rickets resistant to vitamin D. Am $\mathcal{F}$ Dis Child 1937; 54: 529-47.

2 Batch J, Patterson M, Hughes I. Androgen insensitivity syndrome.

Reproductive Medicine Reviews $1992 ; 1: 131-50$.
3 Morris J. The syndrome of testicular feminisation in male pseudohermaphrodites. Am $\mathcal{f}$ Obstet Gynecol 1953; 12: 1-13.

4 Savage M, Grant D. The incomplete male. Arch Dis Child 1978; 53: 701-3.

4 Savage M, Grant D. The incomplete male. Arch Dis Child 1978; 53: 701-3. London: Butterworth, 1989: 111-2.

6 Peterson R, Imperato-McGinley J, Gautier T, Shackleton C. Urinary steroid metabolites in subjects with male pseudohermaphroditism secondary to $5 \mathrm{c} t$ reductase deficiency. Clin Endocrinaol (Oxf) 1985; 23: 49+-500

7 Hughes I, Evans B. The fibroblast as a model for androgen resistant states. Clin Endocrinol (Oxf) 1988; 28: 565-79.

8 Hughes I, Evans B. Androgen insensitivity in forty-nine patients: classification based on clinical and androgen receptor phenotypes. Horm Res 1987; 28: 25-9.

9 Chang C, Kokontis J, Liao S. Molecular cloning of human and rat complementary DNA encoding androgen receptors. Science 1988; 240: 32t-6.

10 Lubahn D, Joseph D, Sullivan P, Willard H, French F, Wilson E. Cloning of human androgen receptor complementary DNA and localization to the $\mathrm{X}$ chromosome. Science 1988; 240: 327-30.

11 Brown C, Goss S, Lubahn D, et al. Androgen receptor locus on the human X chromosome: regional localization to Xq11-12 and description of a DNA polymorphism. Am f Hum Genet 1989; 44: 264-9.

12 Batch J, Williams D, Davies H, et al. Androgen receptor gene mutations identified by SSCP in fourteen subjects with androgen insensitivity
syndrome. Human Molecular Genetics $1992 ; 1: 497-503$.

13 Batch J, Evans B, Hughes I, Patterson M. Mutations of the androgen receptor gene identified in perineal hypospadias. $\mathcal{F}$ Med Genet 1992 (in press).

14 Zoppi S, Marcelli M, Deslypere J-P, Griffin J, Wilson J, MCPhaul MI. Amino acid substitutions in the DNA-binding domain of the human androgen receptor are a frequent cause of receptor-binding positive resistance. Mol Endocrinol 1992; 6: 409-15.

15 Quigley C, Evans B, Simental J, et al. Complete androgen insensitivity due to deletion of exon $C$ of the androgen receptor gene highlights the functional importance of the second zinc finger of the androgen receptor in vivo. Mol Endocrinol 1992; 6: 1103-12.

16 Verp $M$, Simpson J. Abnormal sexual differentiation and neoplasia. Cancer Genet Cytogenet 1987; 25: 191-218.

17 Savage M, Lowe D. Gonadal neoplasia and abnormal sexual differentiation. Clin Endocrinol (Oxf) 1990; 32: 519-33.

18 McPhaul M, Marcelli M, Tilley W, Griffin J, Isidro-Gutierrez R, Wilson J. Molecular basis of androgen resistance in a family with qualitative abnormality of the androgen receptor and responsive to high-dose androgen therapy. $\mathcal{F}$ Clin Invest 1991; 87: 1413-21. 